\title{
LAS COLECCIONES DEL MUSEO NACIONAL DE CIENCIAS NATURALES (CSIC)
}

\author{
E. Moreno (*)
}

\section{Introducción}

Las colecciones de un museo representan su razón de ser, y el hecho de ser el depositario de tales colecciones, lo que justifica su existencia. Por tanto, su principal actividad deberá ir encaminada a la adquisición, conservación, investigación y uso de sus colecciones. Como tal, el Museo Nacional de Ciencias Naturales (CSIC) tiene una gran responsabilidad ya que representa en nuestro país el principal depositario de nuestro patrimonio natural.

Las colecciones de historia natural hunden probablemente sus raíces en el interés del hombre, desde sus orígenes, en el conocimiento de su propia vida y de la de todo lo que lo rodea. Tanto Plinio en su Historia Natural, como Aristóteles en su Historia de los Animales enfatizan la gran diversidad de la gea, la flora y la fauna.

Los orígenes del MNCN están, como los de otros tantos museos de Europa, en los Gabinetes de Historia Natural que tanto proliferaron y tan importante papel desempeñaron en el conocimiento de la naturaleza durante los siglos XVII y XVIII. Nuestro Museo procede del Gabinete de Historia Natural comprado en 1771 a D. Pedro Franco Dávila, quien se convierte poco después en su primer Director, adquiriendo su Gabinete el calificativo de 'Real'. Desde entonces y hasta la fecha muchos y de muy diversa índole han sido los avatares tanto científicos como políticos por los que ha pasado el Museo, y el Padre A.J. Barreiro $(1944,1992)$ hace una minuciosa crónica de ellos en su libro 'El Museo Nacional de Ciencias Naturales (1971-1935)', no siendo pues este, lugar ni momento para referirnos más a ellos.
Quiere esta introducción ser una presentación de las colecciones del MNCN tal y como se encuentran en la actualidad, haciendo hincapié en su valor tanto documental e informativo como en su consideración como herramientas de trabajo en muchas y muy diversas disciplinas de las ciencias naturales, desde la anatomía comparada hasta el estudio evolutivo del crecimiento y desarrollo animal, pasando por la paleobiología, biogeografía, sistemática molecular, taxonomía, estudios de 'life-history', etc.

\section{Las colecciones como fuente de información e investigación}

El Museo representa un importante 'banco' de información, obtenida a partir de sus colecciones de historia natural, información que necesita ser analizada y protegida, pero también puesta a disposición de la sociedad y particularmente de la comunidad científica. Entiendo aquí la palabra 'información' en una doble vertiente. Por un lado, como el conjunto de datos conocidos asociados a cada uno de los elementos que componen las colecciones (e.g., localidad, fecha, etc.). Por otro, me refiero a esa información, llamemos 'potencial' encerrada en dichos elementos, puesta a disposición del investigador y que es sin duda la que da versatilidad a las colecciones, y hace casi indefinida su utilidad en tanto depende única y exclusivamente de la capacidad de dicho investigador de hacerse nuevas preguntas y de encontrar sus respuestas.

Por poner sólo un ejemplo. La variación geográfica en el fenotipo de una especie es, en esencia, un * Vicedirectora de Colecciones, Archivo y Biblioteca. Museo Nacional de Ciencias Naturales. José Gutiérrez Abascal, 2. 28006
Madrid. E-mail: emoreno@fresno.csic.es 
fenómeno estadístico, porque su patrón y magnitud sólo pueden ponerse de manifiesto a partir de muestras de diversas poblaciones repartidas dentro de su rango de distribución. Poder hacer estimas fiables de la variación de un carácter a lo largo de su rango geográfico depende en gran parte de tener o no disponibles series grandes y bien 'datadas' de ejemplares de dicha especie de diferentes lugares. Sin embargo, encontrar una explicación a dicha variación geográfica (e.g., la regla de Gloger aplicable a aves y mamíferos: las poblaciones de una especie que viven en áreas más cálidas y húmedas son más pigmentadas que las que ocupan áreas más frías y secas) puede formar parte de esa información 'potencial' a la que antes me he referido, y es la que el investigador continuamente analiza y explota.

A lo largo de la historia, la utilización de las colecciones de historia natural ha ido cambiando, $\mathrm{y}$ con ella el tipo de investigación realizada con sus ejemplares y la información que de ellos se ha obtenido. Pero la colecciones siguen ahí, desempañando un importante papel en los avances de la investigación biológica y geológica.

\section{Las colecciones: crecimiento y conservación}

En la actualidad el Museo reúne más de cinco millones de ejemplares repartidos en las siguientes colecciones (las peculiaridades de cada una de ellas se detallan en los artículos que siguen a esta introducción): Aves y Mamíferos, Entomología, Geología, Herpetología, Ictiología, Invertebrados (no insectos), Paleobotánica, Paleontología Invertebrados, Paleontología Vertebrados y Prehistoria. Todas ellas representan un importante y valioso legado cultural, altamente vulnerable y que, por tanto, precisa de especial cuidado y protección. Es nuestra responsabilidad conservar en el presente este legado y asegurar su supervivencia en el futuro. Pero no sólo proteger y conservar es importante. Además es una responsabilidad básica de cualquier museo hacer esas colecciones 'útiles y utilizables' a los investigadores por un lado, y a la sociedad por otro. $\mathrm{Y}$ es en este aspecto en el que durante los últimos años se está poniendo un mayor esfuerzo, tanto económico como de personal en nuestro Museo. La inventariación, catalogación y posterior informatización de nuestras colecciones es una de las metas que a más corto plazo se ha propuesto conseguir el Museo, como una forma rápida, sencilla y eficaz de dar a conocer a todo el que lo necesite nuestras colecciones.

Pero además, y aunque a alguien le pueda resultar irónico e incluso no pueda evitar esbozar una sonrisa, las colecciones son algo 'vivo', y como tal algo que continuamente debe crecer. A pesar de que existan millones de ejemplares en las colecciones de los distintos museos del mundo, es esencial expandir dichas colecciones mediante el ingreso de nuevo material. Son necesarias series temporales y geográficas; en determinados casos se hace imprescindible la existencia de ejemplares de distintas clases de edad y en distintos estados de desarrollo; incluso algunas de las nuevas líneas de investigación demandan un nuevo tipo de material que tradicionalmente no ha formado parte de las colecciones de historia natural (e.g., colecciones de criocongelados para estudios de ADN), etc. Sin embargo, y por razones obvias que afectan además a todos los grandes museos del mundo (espacio, presupuesto, personal para gestión, etc.) el crecimiento no puede ser en todas direcciones.

El MNCN pretende poner en marcha en el menor plazo posible una política de colecciones que recoja las necesidades de material de nuestro Museo y marque las líneas prioritarias de su crecimiento, teniendo en cuenta las demandas sociales, didácticas y de investigación no sólo de nuestro país, sino quizá también de su área de influencia.

Publicado, el 30-VI-1998 